Received: 27 February 2019, Revised: 11 March 2019 Accepted: 4 April 2019, Published: 28 April 2019

Available online at: http://e-journal.unair.ac.id/index.php/IMHSJ

\title{
HUBUNGAN DISMENOREA PRIMER DENGAN AKTIVITAS BELAJAR PADA SISWI SMAN 8 SURABAYA
}

\section{CORRELATION BETWEEN PRIMARY DYSMENORRHEA AND LEARNING ACTIVITIES IN SMAN 8 SURABAYA STUDENTS}

\author{
Anggreini Wahyu Prastika ${ }^{1}$, Gadis Meinar Sari ${ }^{2}$, Gatut Hardianto ${ }^{2}$ \\ 1. Program Studi Pendidikan Bidan, Fakultas Kedokteran, Universitas \\ Airlangga \\ 2. Fakultas Kedokteran, Universitas Airlangga \\ Alamat korespondensi: \\ Jl. Gajahmada 4 Blok C/9, Mojokerto, 61318 Indonesia \\ Email : anggreiniwp12@gmail.com
}

\begin{abstract}
Abstrak
Latar Belakang : Aktivitas belajar merupakan proses belajar, baik kegiatan fisik maupun psikis. Aktivitas belajar siswa dipengaruhi oleh beberapa faktor. Keluhan yang sering dirasakan oleh remaja putri yaitu nyeri saat menstruasi (dismenorea). Dismenorea adalah rasa nyeri perut bagian bawah yang menjalar ke kaki ataupun punggung yang timbul saat atau menjelang haid. Pada anak remaja usia sekolah, dismenorea dapat mengganggu aktivitas belajar sehari-hari. Saat seorang remaja putri mengalami dismenorea, hal tersebut dapat membuat mereka tidak masuk sekolah. Penelitian ini bertujuan untuk mengetahui hubungan antara dismenorea primer dengan aktivitas belajar. Metode : Penelitian ini adalah analitik observasional dengan desain cross sectional di SMAN 8 Surabaya yang dilakukan bulan maret sampai juni 2019. Sampel yang digunakan sebanyak 58 siswi SMAN 8 Surabaya yang diambil dengan metode Purposive Sampling. Data dianalisa menggunakan analisis bivariat menggunakan uji Chi Square. Hasil : Hasil uji statistik menunjukkan tidak ada hubungan yang bermakna antara dismenorea primer dengan aktivitas belajar pada siswi SMAN 8 Surabaya dengan $(P$ 0,834). Kesimpulan : Tidak terdapat hubungan antara dismenorea primer dengan aktivitas belajar.
\end{abstract}

Kata kunci : dismenorea primer, aktivitas belajar

\begin{abstract}
Background: Learning activities are a learning process both in physical and psychological activities. Student learning activities are influenced by several factors. Complaints that are often felt by female adolescents are menstrual pain (dysmenorrhea). Dysmenorrhea is a pain in the lower abdomen that spreads to the legs or back that arises during or before menstruation. In adolescents, dysmenorrhea can interfere with daily learning activities. When a female adolescents experiences dysmenorrhea, it can make them not attend school. This study aims to determine the relationship between primary dysmenorrhoea and learning activities. Method: This study was an observational analytic with cross sectional design at SMAN 8 Surabaya conducted in March to June 2019. The sample used were 58 female students of SMAN 8 Surabaya taken by purposive sampling method. Data were analyzed using bivariate analysis using the Chi Square test. Result : The results of the statistical test showed there is no significant relationship between primary dysmenorrhea and learning activities in female students of SMAN 8 Surabaya with (P 0.834).Conclusion : There is no relationship between primary dysmenorrhoea and learning activities.
\end{abstract}

Keywords: primary dysmenorrhea, learning activities 


\section{PENDAHULUAN}

Remaja adalah generasi muda yang penting dari suatu negara. Pemerintah telah mengupayakan peningkatan kualitas sumber daya manusia khususnya remaja. Pada bidang pendidikan dilakukan program wajib sekolah, Kartu Indonesia Pintar, dan program lain untuk memudahkan masyarakat untuk mendapat pendidikan (Shidiq, 2018). Dalam peningkatan kualitas pendidikan terjadi hambatan, salah satunya diakibatkan aktivitas belajar.

Aktivitas belajar merupakan kegiatan siswa dalam proses belajar, baik kegiatan fisik maupun kegiatan psikis. Belajar membutuhkan fisik yang sehat, fisik yang sehat mempengaruhi jaringan tubuh sehingga aktivitas belajar baik. Sakit pada fisik atau tubuh mengakibatkan cepat lemah, kurang bersemangat, mudah pusing, dan lainnya (Rohmat, 2013). Keluhan yang sering dirasakan oleh remaja putri yaitu nyeri saat menstruasi (dismenorea). Dismenorea adalah rasa nyeri yang dirasakan saat atau menjelang haid, di perut bagian bawah yang menjalar ke kaki ataupun punggung (Beddu, Mukarramah dan Lestahulu, 2015)

Menurut Bajrai dalam (Murtingsih, 2015) dismenorea primer adalah nyeri yang terjadi 6-12 bulan setelah menarche karena adanya peningkatan prostaglandin yang menimbulkan terjadinya kontraksi uterus. Dismenorea terjadi karena ketidakseimbangan hormon prosgesteron dalam darah yang menimbulkan rasa nyeri (Istiqomah, 2009). Dismenorea sekunder adalah nyeri yang terjadi akibat adanya gangguan pada pelvik atau uterus. Pada remaja usia sekolah, dismenorea dapat mengganggu aktivitas belajar sehari-hari. Aktifitas belajar yang terganggu seperti tidak mampu memperhatikan penjelasan guru, hal tersebut dikarenakan mereka fokus merasakan dismenorea yang terjadi sehingga konsentrasi dan motivasi belajar menurun (Ningsih, 2011). Saat seorang remaja putri mengalami dismenorea, tidak jarang hal tersebut juga dapat membuat mereka tidak masuk sekolah.

Tujuan dari penelitian ini adalah untuk mengetahui hubungan antara dismenorea primer dengan aktivitas belajar pada siswi SMAN 8 Surabaya. Hipotesis penelitian ini "ada hubungan antara dismenorea primer dengan aktivitas belajar pada siswi SMAN 8 Surabaya Jawa Timur". 


\section{METODE}

Penelitian ini dilakukan di SMAN 8 Surabaya. Desain penelitian yang digunakan dalam penelitian ini adalah crossectional. Populasi yang digunakan dalam penelitian ini adalah semua siswi SMAN 8 Surabaya tahun ajaran 2019/ 2020. Sampel yang digunakan dalam penelitian ini adalah siswi yang memenuhi kriteria inklusi dan eksklusi. Teknik pengambilan data yang digunakan dalam penelitian ini adalah purposive sampling berdasarkan kriteria inklusi dan eksklusi. Besar sampel yang digunakan dalam penelitian ini adalah 58 orang.

Tabel 1 Definisi operasional variabel penelitian

\begin{tabular}{|c|c|c|c|c|}
\hline Jenis Variabel & $\begin{array}{l}\text { Definisi } \\
\text { Operasional }\end{array}$ & Cara Ukur & Kriteria & Skala \\
\hline $\begin{array}{l}\text { Dismenorea } \\
\text { Primer }\end{array}$ & $\begin{array}{l}\text { Rasa nyeri pada perut } \\
\text { bagian bawah yang } \\
\text { terjadi saat menstruasi } \\
\text { tanpa adanya penyakit } \\
\text { patologis pada rahim } \\
\text { (Prawirohardjo, 2014). }\end{array}$ & $\begin{array}{l}\text { Kuesioner } \\
\text { NRS }\end{array}$ & $\begin{array}{ll}\text { 1. } & \text { Normal }=0 \\
\text { 2. } & \text { Ringan }=1-3 \\
\text { 3. } & \text { Sedang }=4-6 \\
\text { 4. } & \text { Berat =7-9 } \\
\text { 5. } & \text { Berat sekali }=10\end{array}$ & Ordinal \\
\hline $\begin{array}{l}\text { Aktivitas } \\
\text { Belajar }\end{array}$ & $\begin{array}{l}\text { Kegiatan - kegiatan baik } \\
\text { secara fisik atau mental } \\
\text { yang dilakukan dalam } \\
\text { proses interaksi antara } \\
\text { guru dan siswa sehingga } \\
\text { dapat mencapai tujuan } \\
\text { belajar (Iin, 2012). }\end{array}$ & $\begin{array}{l}\text { Kuesioner } \\
\text { Likert }\end{array}$ & 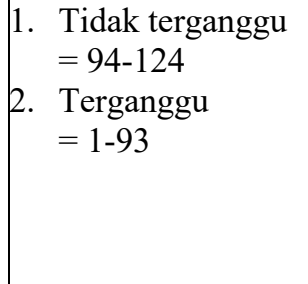 & Nominal \\
\hline
\end{tabular}

Pengumpulan data dalam penelitian ini menggunakan kuesioner yang langsung diberikan kepada siswi SMAN 8 Surabaya. Kuesioner yang digunakan adalah kuesioner tertutup dengan rangkaian kuesioner yang terdiri dari karakteristik responden, intensitas nyeri, dan aktivitas belajar. Pengolahan data dilakukan dengan editing, coding, scoring, data entry, dan tabulating. Analisis data dalam penelitian ini menggunakan uji Chi Square dengan tingkat kepercayaan 95\% yang diolah menggunakan program computer SPSS. Uji ini dilakukan untuk mengetahui ada tidaknya hubungan antara dismenorea primer dengan aktivitas belajar dengan nilai signifikasi $\alpha=0,05$. 


\section{HASIL DAN PEMBAHASAN}

Tabel 2 Hubungan dismenorea primer dengan aktivitas belajar

\begin{tabular}{|c|c|c|c|c|c|c|}
\hline \multirow{2}{*}{$\begin{array}{c}\text { Dismenorea } \\
\text { Primer }\end{array}$} & \multicolumn{4}{|c|}{ Aktivitas Belajar } & \multirow[t]{2}{*}{ Jumlah } & \multirow{3}{*}{ p value } \\
\hline & \multicolumn{2}{|c|}{ Terganggu } & \multicolumn{2}{|c|}{ Tidak Terganggu } & & \\
\hline Intensitas & $f$ & $\%$ & $f$ & $\%$ & Total & \\
\hline Ringan & 18 & 46,2 & 21 & 53,8 & 39 & \\
\hline Sedang & 7 & 50,0 & 7 & 50,0 & 14 & 0,834 \\
\hline Berat & 3 & 60,0 & 2 & 40,0 & 5 & \\
\hline Total & 28 & 48,3 & 30 & 51,7 & 58 & \\
\hline
\end{tabular}

Tabel 2 menunjukkan mayoritas responden mengalami aktivitas belajar yang tidak terganggu yaitu sebanyak 30 siswi $(51,7 \%)$ dengan kategori dismenorea ringan yang paling besar yaitu sebesar 21 siswi (51,8\%). Hasil uji chi square menunjukkan nilai $\mathrm{p}$ value $>0,05(\mathrm{p}$ value $=0,834)$ yang artinya tidak terdapat hubungan yang signifikan antara dismenorea primer dengan aktivitas belajar pada siswi SMAN 8 Surabaya.

Hasil penelitian ini menunjukkan aktivitas terganggu terjadi pada 18 siswi $(24,7 \%)$ dengan dismenorea ringan, 7 siswi $(9,6 \%)$ dismenorea sedang, 3 siswi $(4,1 \%)$ dismenorea berat. Hal tersebut menunjukkan aktivitas belajar siswa cukup terganggu dengan dismenorea primer yang dialami. Dismenorea merupakan penyebab utama remaja putri absen di sekolah dalam beberapa jam ataupun hari. Hal tersebut dikaitkan dengan pengaruh negatif terhadap aktivitas belajar sosial remaja putri. Remaja putri yang mengalami dismenorea lebih banyak absen di sekolah dan memiliki prestasi kurang begitu baik dengan siswi yang tidak mengalami dismenorea menurut Kurniawati (Handayani, 2011).

Hasil penelitian ini sejalan dengan hasil penelitian (Sumartini, 2014) mengenai hubungan dysmenorrhea dengan prestasi belajar mahasiswi jurusan keperawatan angkatan 2011 Fakultas Ilmu Kesehatan UIN Alauddin Makassar. Hasil uji statistik dengan uji Chi-square didapatkan nilai $p=0,614>\alpha=0,05$. Hal tersebut menyatakan bahwa tidak ada hubungan antara dysmenorrhea dengan prestasi belajar.

Hasil penelitian ini tidak sesuai dengan hasil penelitian Setiawan \&Linda (2018) mengenai hubungan nyeri haid (dismenore) dengan aktivitas belajar seharihari pada remaja putri kelas vii di SMPN 3 Pulung. Hasil uji statistiknya menunjukkan bahwa berdasarkan uji statistik rho Spearman didapatkan nilai $\mathrm{r}$ sebesar 0,602 dengan nilai $\mathrm{p}$ sebesar 0,000. Hal tersebut menyatakan bahwa 
terdapat hubungan antara dismenorea primer dengan aktivitas belajar siswi kelas vii SMPN 3 Pulung.

Selain itu penelitian ini juga tidak sesuai dengan penelitian Iswari (2014) mengenai hubungan dismenore dengan aktivitas belajar mahasiswi PSIK FK UNUD. Hasil uji statistik menggunakan rho Spearman didapatkan p sebesar 0,01 dimana $\mathrm{p}<0,05$, dimana nilai tersebut menyatakan bahwa ada hubungan antara dismenorea dengan aktivitas belajar.

Dismenorea tidak dapat dijadikan sebagai satu-satunya faktor yang mempengaruhi terganggunya aktivitas belajar. Walaupun tingkat kemaknaan menunjukkan tidak ada hubungan antara dismenorea primer dengan aktivitas belajar, tetapi dismenorea tidak dapat diabaikan. Berdasarkan hasil penelitian dapat dilihat bahwa semakin meningkatnya dismenorea maka persentase gangguan aktivitas belajarnya semakin tinggi. Sedangkan pada aktivitas belajar tidak terganggu semakin tinggi derajat dismenoreanya maka semakin rendah pula persentasenya. Hasil tersebut dikarenakan sebagian besar yang menjadi responden mengalami dismenorea ringan. Jika yang menjadi responden memiliki mayoritas dismenorea berat maka hasil tingkat kemaknaannya dapat berubah.

Selain intensitas dismenorea, tingkat pengetahuan juga mempengaruhi hasil. Semakin siswi tersebut paham tentang dismenorea maka siswi tersebut dapat memberikan toleransi pada dirinya saat mengalami menstruasi. Hal itu dapat menyebabkan siswi yang mengalami dismenorea dengan intensitas berat dapat menahan dismenorea yang dirasakan hingga dapat menurunkan tingkat dismenorea yang dirasakan.

Dari penelitian ini dapat disimpulkan bahwa aktivitas belajar dapat terganggu dari banyak faktor baik psikis maupun fisik. Belajar membutuhkan fisik yang sehat, karena hal tersebut akan mempengaruhi seluruh bagian tubuh sehingga aktivitas belajar tidak rendah. Keadaan yang sakit dapat membuat tubuh cepat lemah, kurang bersemangat, dan lainnya. Oleh karena itu agar dapat memiliki aktivitas belajar yang baik, seseorang harus menjaga diri agar memiliki fisik dan psikis yang sehat. 


\section{SIMPULAN DAN SARAN}

Sebagian besar siswi SMAN 8 Surabaya yang menjadi responden mengalami dismenorea ringan dengan mayoritas siswi tidak mengalami gangguan aktivitas belajar. Tidak terdapat hubungan antara dismenorea primer dengan aktivitas belajar pada siswi SMAN 8 Surabaya dalam penelitian ini. Dismenorea tidak dapat diabaikan, karena beberapa faktor seperti karakteristik responden, lokasi, status gizi, dan aktivitas siswa dapat mempengaruhi dismenorea.

Sebaiknya dilakukan penelitian lebih lanjut dengan menambahkan faktor yang lain seperti usia menarche, status gizi, tingkat stress, tingkat pengetahuan, dan tingkat olahraga. Selain itu perlu dilakukan penyuluhan dan konseling mengenai kesehatan reproduksi terutama disemenorea primer. Hal tersebut dapat membantu siswi agar dapat mengtasi rasa sakit yang terjadi saat nyeri menstruasi. Bagi responden diharapkan lebih peduli dengan kondisi tubuhnya sehingga saat mengalami dismenorea aktivitas belajar mereka tidak terganggu. Responden disarankan untuk melakukan pola hidup sehat seperti rutin berolahraga, mengkonsumsi makanan yang bergizi seimbang, dan istirahat yang cukup.

\section{DAFTAR PUSTAKA}

Beddu, S., Mukarramah, S. dan Lestahulu, V. (2015) "Hubungan Status Gizi dan Usia Menarche Dengan Dismenore Primer pada Remaja Putri," SEAJOM: The Southeast Asia Journal of Midwifery, 1, hal. 16-21. doi: 10.36749/seajom.vli1.53.

Handayani, T. Y. (2011) "Hubungan Dismenorea Terhadap Aktivitas Belajar Siswi Sma Muhammadiyah 5 Yogyakarta Tahun 2011 Program Studi Bidan Pendidik Jenjang Div Sekolah Tinggi Ilmu Kesehatan ' Aisyiyah Yogyakarta Tahun 2011," jurnal penelitian DIV sekolah tinggi ilmu kesehatan. Tersedia pada: http://digilib.unisayogya.ac.id/1580/1/NASKAH PUBLIKASI.pdf.

Istiqomah, P. (2009) "Efektivias Senam Disminore Dalam Mengurangi Dismenore Pada Remaja Putri Di SMU N 5 Semarang," Program Studi Ilmu Keperawatan Universitas Diponegoro. Tersedia pada: https://core.ac.uk/download/pdf/11709709.pdf.

Murtiningsih,L.K. (2015) "Penurunan Nyeri Dismenorea Primer Melalui Kompres Hangat pada Remaja". Tersedia pada: http://jkp.fkep.unpad.ac.id/index.php/ jkp/article/ viewfile/104/100

Ningsih, R. (2011) "Efektivitas Paket Pereda Terhadap Intensitas Nyeri pada Remaja dengan Dismenorea Di SMAN Kecamatan Curup". Tersedia pada: http://lib.ui.ac.id/file? file=digital/20282111T\%20Ratna\%20Ningsih \%20.pdf

Prawirohardjo. (2014) "Ilmu Kandungan”. Jakarta : Bina Pustaka Sarwono 
Rohmat, N. (2013). Upaya Meningkatkan Aktivitas Belajar Siswa dalam Mata Pelajaran PKN Materi Pokok Peraturan Perundang- Undangan Tingkat Pusat dan Daerah Kelas V Melalui Model Pembelajaran Berbasis Masalah (Problem Based Learning) di MI Miftahus Sibyan Tugurejo Semarang. http://eprints.walisongo.ac.id/984/

Setiawan,S.A \& Linda,L. (2018). Hubungan Nyeri Haid (Dismenore) dengan Aktivitas Belajar Sehari-hari Remaja Pitri Kelas VII Di SMPN Pulung.

Shidiq, A.F \& Santoso. T.R . (2018). Peran Pendidikan Karakter di Masa Remaja Sebagai Pencegahan Kenakalan Remaja. Prosiding Penelitian \& Pengabdian Kepada Masyarakat. Vol. 5, No.2, Hal: 176-187

Sumartini, (2014). Hubungan Dysmenorrhea dengan Prestasi Belajar Mahasiswi Jurusan Keperawatan Angkatan 2011 Fakultas Ilmu Kesehatan UIN AlauddinMakassar.http://repositori.uinlauddin.ac.id/6607/1/SUMARTIN I_opt.pdf 